\title{
Introduction to the Proceedings of the 19th Jan Tinbergen European Peace Science Conference
}

\author{
${ }^{1}$ Department of Politics, University of York, Heslington, York, UK \\ ${ }^{2}$ Center for Security Studies, ETH Zurich, Zurich, Switzerland, E-mail: enzo.nussio@sipo.gess.ethz.ch
}

DOI: 10.1515/peps-2019-0047

The $19^{\text {th }}$ Jan Tinbergen European Peace Science conference took place at the Institute of Social Studies in the Hague 24-26 June, 2019. Nearing the $20^{\text {th }}$ anniversary of the establishment of the annual conference, it continues to be a vibrant international and interdisciplinary meeting with presentations engaging in broader theoretical and empirical debates as well as introductions to much needed new data collections in the conflict and peace science community. This special issue is a collection of some of the papers presented at the conference in the format of letters. Overall, the proceedings include 12 letters, which are short versions of the on-going research projects in the field of peace science broadly defined. ${ }^{1}$

This year, the topics reflect the diverse range of innovative approaches in studying peace and conflict. The first letter in the proceedings is the annual NEPS lecture by Jean-Paul Azam. This paper is deservedly the opening letter for the special issue as the NEPS lecture is the keynote of the conference, established to acknowledge the significant contribution the individual has made in the area of peace science. ${ }^{2}$ Jean-Paul's lecture shows how instrumental variables can be used to evaluate policy effectiveness using historical data through an example from the Naxalite conflict in India. The article starts by highlighting how misleading regression results can be without proper instrumentation and worse yet, how such misleading findings can be used as basis for decisions by policy-makers for decades before such errors are identified. In order for econometricians to avoid making such mistakes in evaluating policy effectiveness, they need to uncover the policy maker's true preferences (which are often at odds with the official ones) by controlling for the policy maker's endogenous responses.

The next letter in the proceedings follows naturally from Azam's lecture as it introduces the work and contributions of the winner of the 2019 Lewis Fry Richardson Award: Jean-Paul Azam. Here Thelen, Gates, and Bhatia highlight how Azam's work on explaining violent conflict and its prevention is highly deserving of the Lewis Fry Richardson Award due to being in the 'spirit and nature of Lewis' work on violence and armed conflict'. The authors describe Azam's contribution in peace science through his research in areas such as terrorism and foreign aid, civilian targeting and civil wars with the use of formal theoretical models and econometric analysis.

The remainder of the special issue includes articles in three broad categories: new data collection projects in the area of peace and conflict, empirical case studies of Mexico and Liberia, as well as letters researching foreign policy and behaviour of states in the international arena.

In terms of the data collection articles, in the first article Huber and Basedau introduce their newly created Religious Minorities at Risk dataset, which covers overall 771 religious minorities worldwide from 2000 to 2014. The dataset also includes information about objective deprivation and subjective grievances of these groups. While there are increasingly more data available on ethnic divisions and grievances, there are much less systematic data on religion. Huber and Basedau's data collection efforts will thus be very useful for students of religion and conflict. Mousseau, Napolitano and Olsen on the other hand focus on human rights violations during the Kurdish conflict in Turkey. Their newly collected dataset codes information about different types of human rights violations against different targets perpetrated by the belligerents during the years 1990-2018. Thanks to this data, we can explore whether and to what extent the different parties in the Kurdish conflict abide by international norms. Furthermore, the authors base their data collection on a framework that could be applied to other contexts as well. Finally, Otto dives into an understudied aspect of peacekeeping missions their deployment of civilian personnel. She demonstrates through the use of exploratory descriptive statistics that the deployment of civilian personnel in UN peacekeeping missions may have an effect on human rights violations during civil wars. However, as her research project demonstrates, more data are required to interrogate the under-researched area of the civilian side of peacekeeping. In her conclusion, she also specifies several research avenues for the future, which may be helpful for other researchers in this field. 
The case study letters focus on Liberia and Mexico, and individual level perceptions and behavior. Similarly to Otto, Leib's article studies the effects of peacekeeping, but instead of focusing on data collection, her research uses process tracing to understand how locals perceive the peace process in Liberia, specifically the security and justice mechanisms. Her findings suggest that while the peacekeeping mission was considered very important in the peacebuilding process, the Truth and Reconciliation Commission did not contribute to reconciliation in Liberia the way it was supposed to. While Balmori's article focuses on war rather than peace, this second empirical case study of the proceedings highlights the impact of violence during the Mexican drug war on avoidance behavior. By using a fixed effects and instrumental variable approach as identification strategy, the study finds that due to the drug war violence, respondents show increased avoidance behavior. However, certain types of avoidance behavior are more likely (such as avoiding to go out at night) than others, when respondents have less of a choice (such as using public transportation).

The last group of articles shifts our focus from within country analysis to state behaviour in the international sphere. Mousseau contributes to the debate of democratic peace by showing four different ways in which the democratic peace correlation can be challenged. In a thought-provoking piece, he revisits the cumulated evidence on this long-ranging debate. He finds little evidence that the democratic peace correlation holds. Importantly, he suggests that it is the contractualist economy - where people depend on the impersonal marketplace rather than on their groups and leaders - which causes both democracy and peace. Lutmar and Mandler examine the impact of bilateral foreign aid allocation by Israel on the voting at the UN General Assembly in relation to Israel by the recipient states. The authors find that the often-anticipated effect of support of the donor by the aid recipient does not seem to exist in UN voting, at least in the long term. Hence, foreign aid as a diplomatic tool does not produce the effects one would expect in the case of Israel. Instead of foreign aid allocation, Bergeijk, Demena, Reta, Benalcázar and Kimararungu conduct a meta-analysis of economic sanctions and their effectiveness in the existing academic literature. The study is motivated by the lack of consensus in the past research about determinants of economic sanctions success. Indeed, their findings about trade linkages, sanction duration and prior relations between the sender and recipient suggest that the findings do not converge in the literature and that the reason for this is publication bias favouring prior beliefs or statistical significance. In keeping with the theme of economic foreign policy decisions, Callado, Hromcova, and Utrero are interested in the relationship between military alliances and trade. They use the North Atlantic Treaty Organization (NATO) member countries and partners in their empirical approach and find that being a member or a NATO partner increases the arms imports coming from other alliance countries and this effect holds even when taking into account other economic and country specific factors. This is a welcome contribution to the understanding of the interplay between political alliances and trade. Similarly to Callado, Hromcova, and Utrero, Hellemeier also studies the economic aspect of state decision-making, specifically aircraft procurement decisions. Why do some European countries procure fighter jets from the US given the importance of European strategic autonomy in military defense? An explanation of subordination to the US receives most support in his empirical analysis.

In summary, these articles demonstrate the diversity of topics as well as the state-of-the art empirical approaches that the NEPS conference participants use in their research. In particular, the guest editors were delighted to review three new data collection articles, as these are undoubtedly valuable public goods for the community of peace science scholars. While earlier conference proceedings have mentioned the need to focus on the disaggregated and subnational dynamics of conflicts, this year the contributions included a good mix of both micro and macro level analysis of peace and conflict. Specifically, this issue includes two empirical case studies investigating the effect of violence and peace processes in Mexico and Liberia. On the macro level, this special issue includes articles challenging the democratic peace thesis as well as explaining foreign policy decision-making through trade and foreign aid. Overall, this special issue is a testament to the quality of work presented at the $19^{\text {th }}$ Jan Tinbergen annual meeting.

\section{Notes}

1 For proceedings of previous Jan Tinbergen Conferences, see Caruso (2018), Kibris and Haer (2017), Meierrieks and Caruso (2016), Haer and Kibris (2015), Caruso and Gizelis (2014), Böhmelt and Sekeris (2013), and Bove and Ruggeri (2012).

2 For the most recent keynote lectures, see Gizelis (2018), Slantchev (2017), Buhaug (2016), and Shortland (2015).

\section{References}

Böhmelt, T., \& Sekeris, P. G. (2013). Introduction. Peace Economics, Peace Science and Public Policy, 19(3), 285-290.

Bove, V., \& Ruggeri, A. (2012). Introduction. Peace Economics, Peace Science and Public Policy, 18(3), 1-4. 
Buhaug, H. (2016). Climate change and conflict: taking stock. Peace Economics, Peace Science and Public Policy, 22(4), 331-338.

Caruso, R. (2018). Introduction to the Proceedings of the 18th Jan Tinbergen European Peace Science Conference. Peace Economics, Peace Science and Public Policy, 24(4), 1-2.

Caruso, R., \& Gizelis, T.-I. (2014). Introduction to the Proceedings of the 14th Jan Tinbergen European Peace Science Conference. Peace Economics, Peace Science and Public Policy, 20(4), 523-526.

Gizelis, T.-I. (2018). Systematic study of gender, conflict, and peace. Peace Economics, Peace Science and Public Policy, 24(4), 1-10.

Haer, R., \& Kıbris, A. (2015). Introduction to the Proceedings of the 15th Jan Tinbergen European Peace Science Conference. Peace Economics, Peace Science and Public Policy, 21(4), 415-418.

Kibris, A., \& Haer, R. (2017). Introduction to the Proceedings of the 17th Jan Tinbergen European Peace Science Conference. Peace Economics, Peace Science and Public Policy, 23(4), 1-2.

Meierrieks, D., \& Caruso, R. (2016). Introduction to the Proceedings of the 16th Jan Tinbergen European Peace Science Conference. Peace Economics, Peace Science and Public Policy, 22(4), 327-330.

Shortland, A. (2015). Can we stop talking about Somali piracy now? a personal review of Somali piracy studies. Peace Economics, Peace Science and Public Policy, 21(4), 419-431.

Slantchev, B. L. (2017). On the Proper use of game-theoretic models in conflict studies. Peace Economics, Peace Science and Public Policy, 23(4), 1-14. 